\title{
Elaboration of Aromatic Extracts From the Industrial Waste of White Shrimp
}

\author{
R. Bernadino Filho ${ }^{1}$, Osvaldo S. Silva ${ }^{2}$, Lucivânia A. O. Navarro ${ }^{3}$, Artur X. M. de Queiroga ${ }^{2}$, \\ Silvana N. Oliveira ${ }^{1}$, Marcela N. Oliveira ${ }^{2} \&$ Ubieli A. A. Vasconcelos ${ }^{4}$ \\ ${ }^{1}$ Garanhuns Academic Unit, Federal Rural University of Pernambuco, Garanhuns, PE, Brazil \\ ${ }^{2}$ Science and Technology Center, Federal University of Campina Grande, Campina Grande, PB, Brazil \\ ${ }^{3}$ Jundiaí Agricultural School, Federal University of Rio Grande do Norte, Macaíba, RN, Brazil \\ ${ }^{4}$ Federal University of Viçosa, Viçosa, MG, Brazil \\ Correspondence: R. Bernadino Filho, Garanhuns Academic Unit, Federal Rural University of Pernambuco, \\ Garanhuns, PE, Brazil. Tel: 55-879-9984-3810. E-mail: raimundobfh@gmail.com
}

Received: January 16, 2019

doi:10.5539/jas.v11n6p218
Accepted: March 3, 2019 Online Published: May 15, 2019

URL: https://doi.org/10.5539/jas.v11n6p218

\begin{abstract}
The objective of this research was the elaboration of extracts from the solid industrial waste of Litopenaeus vannamei shrimp and to define the extract with the highest acceptance rate and highest extraction yield through physicochemical, microbiological and sensorial analysis. The extracts were obtained through a process of lyophilization of the liquid extracts from the baking of the waste. Three types of extracts were prepared with different raw materials: $\mathrm{E}_{\text {casca }}$ (shells), $\mathrm{E}_{\text {cefa }}$ (cephalothorax) and $\mathrm{E}_{\text {mix }}(50 \%$ shells $\pm 50 \%$ cephalothorax). With the exception of humidity, all other physical-chemical parameters presented significant differences between them. All data from the microbiological analysis were within the limits required by current Brazilian legislation. In the sensory evaluation, all the extracts were well accepted, the $\mathrm{E}_{\text {cefa }}$ being the treatment that obtained the highest index of acceptability for the aroma and flavor. The $\mathrm{E}_{\text {cefa }}$ treatment obtained the highest extraction yield. In view of the obtained data, it was possible to determine that the $\mathrm{E}_{\text {cefa }}$ treatment would have a greater potential as an extract to be applied in foods that can present shrimp aroma and flavor, thus contributing to the use of shrimp industry waste in the offer of a natural aromatic extract and for the preservation of the environment by avoiding the disposal of such waste improperly.
\end{abstract}

Keywords: crustacean, flavor, fish, flavoring, sensory test

\section{Introduction}

The waste of by-products and waste by the food industry has become increasingly worrying both economically and environmentally, as they are real sources of pollution. In the case of fishery resources, especially crustaceans, industrialization generates large amounts of waste that can compromise the environment when not utilized or discarded inappropriately (Gonçalves, 2011).

The shrimp produced in the industries is usually marketed in fresh, frozen whole, headless and/or peeled form. According to Seibel and Soares (2003), the waste of some crustaceans, depending on the species and the processing, reach $85 \%$ of the initial weight. In the specific case of the species Litopenaeus vannamei, the cephalothorax (head) and shell constitute approximately $40 \%$ of its total weight, which generally continues to be discarded by the processing units without any kind of technological use (Gildberg \& Stemberg, 2001).

The cephalothorax and shell are the main waste generated in shrimp industrialization, in which several components such as proteins, lipids, chitin, carotenoids, aromatic and mineral compounds are present, whose percentages vary according to species, constituent parts, fishing location and seasonal variation (Nogueira, 2006) Some studies have been carried out regarding the use of these wastes, looking for alternatives to their final disposal, with a view to the development of products of added value and high nutritional value, however, their industrial and even artisanal use is still incipient.

Potentially, three by-products can be isolated from the cephalothorax and shrimp shell, which are the carotenoid pigments, chitin/chitosan and flavor extract, which are of great use in the food and animal feed industry (Rocha, 
Nunes, \&Fioreze, 1998). Shrimp head extract, also known as flavoring, can be used in a range of foods, mainly in products based on mechanically separated fish (CMSP) or surimi, such as fishburgers, kamaboko, chikuwa, sausages, other analogous foods of marine origin (Basílio, Ogawa, Perdigão, \& Vasconcelos, 2003).

Given this scenario, it is necessary to treat these wastes that are considered potential sources of pollution to the environment, preferably with their use directed to the food sector contributing to the added value and increased profitability of the fishing industry. Thus, the objective of this research was the preparation of extracts from the solid industrial waste (cephalothorax and shells) of Litopenaeus vannamei shrimp and through physicochemical, microbiological and sensorial analysis to define the extract with the highest acceptance rate and highest extraction yield.

\section{Material and Methods}

\subsection{Raw Material}

The raw material used to obtain the aromatic extracts was composed of waste-cephalothorax and shell of white Pacific prawn (Litopenaeus vannamei) obtained by manual peeling from a shrimp processing industry located in Macaíba/RN, Brazil. The shrimp used were caught in the summer period in Brazil, from nurseries, collected after the commercial size.

The shrimp waste was collected in the industry in fresh refrigerated form and transported in isothermal containers with ice to the Fish Processing Laboratory located at Escola Agrícola de Jundiaí/EAJ (Agricultural School of Jundiaí) of Universidade Federal do Rio Grande do Norte/UFRN (Federal University of Rio Grande do Norte). After removing the impurities manually, the residue was sanitized in chlorinated water at $10 \mathrm{ppm}$ according to hygienic standards used in the food industries and subjected to freezing $\left(-20^{\circ} \mathrm{C}\right)$ for further analysis and extraction of aromatic extracts.

\subsection{Obtenção Dos Extratos Aromáticos}

The flowchart in Figure 1 shows the sequence of operations to obtain the primary extracts that served as the basis for defining the extract of the best extractive yield profile and sensory acceptance. All extracts were obtained following the same flowchart, with only the raw materials being divided into three types: $\mathrm{E}_{\text {casca }}$ (shells), $\mathrm{E}_{\text {cefa }}$ (cephalothorax) and $\mathrm{E}_{\text {mix }}(50 \%$ Shell and 50\% cephalothorax).

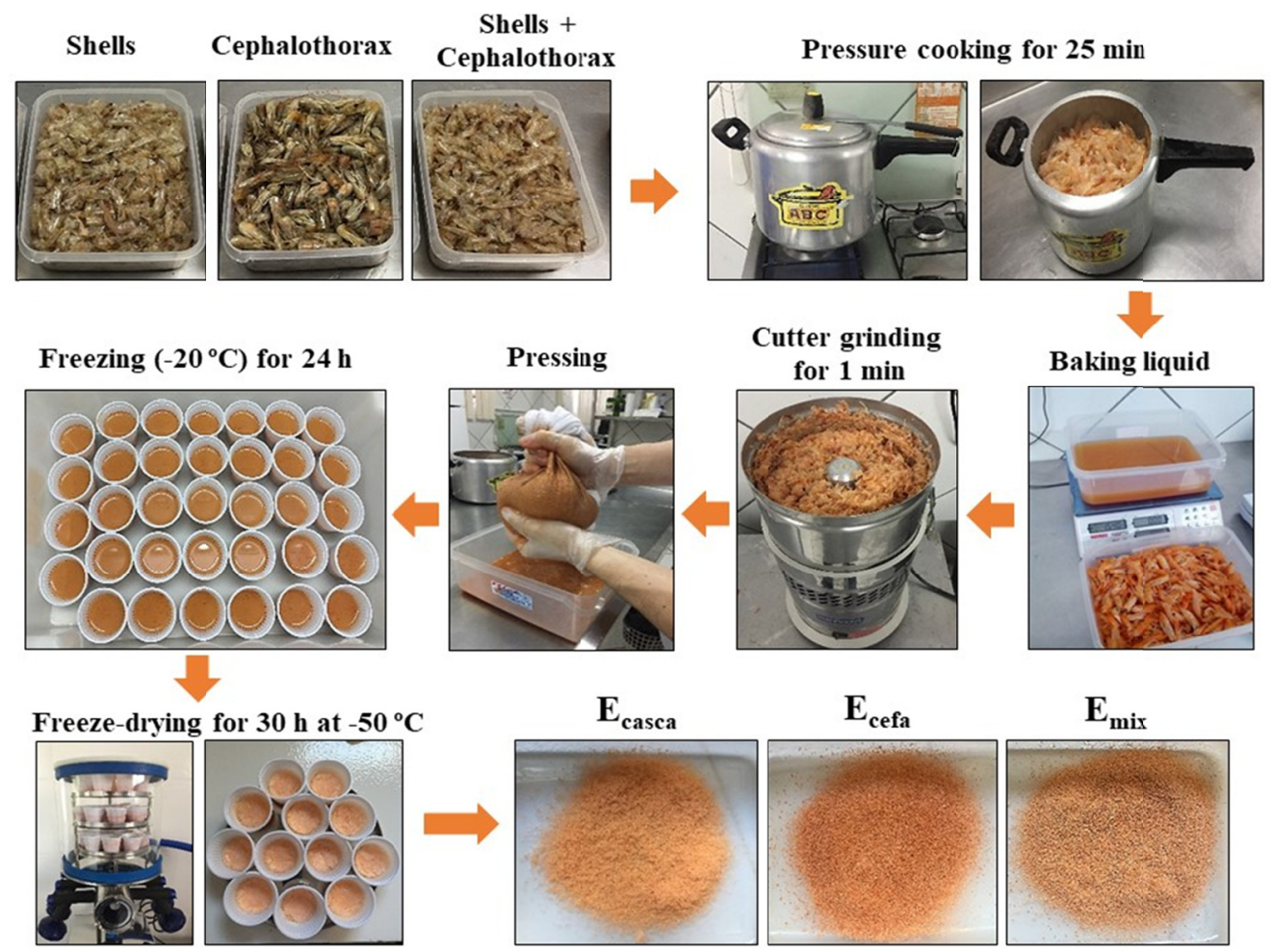

Figure 1. Flowchart for obtaining aromatic extracts from shrimp waste

Source: R. Bernadino Filho, 2018. 
The extracts were obtained based on the methodology proposed by Takeshita (1981) by a process of pressure cooking the waste at approximately $100^{\circ} \mathrm{C}$ for 25 minutes in the ratio $1: 2$ water/waste. The liquid resulting from the baking was collected and the waste was ground in a cutter for 1 minute and then pressed into bags of cotton cloth, the pressing extract of which was mixed into the cooking liquid forming a mixture, the mixture was frozen in a refrigerator at $20{ }^{\circ} \mathrm{C}$ for 24 hours and then freeze-dried at $-50{ }^{\circ} \mathrm{C}$ and stored in plastic packaging until the microbiological, physical-chemical and sensorial analysis were performed.

\subsection{Microbiological, Physicochemical and Sensorial Analysisof Freeze-Dried Extracts}

All microbiological analysis were performed according to the methodologies proposed by the American Public Health Association (APHA, 2001). The analyses were performed for the following microorganisms: positive Staphylococcus coagulase, Salmonella sp. and Coliforms at $45^{\circ} \mathrm{C}$, proposed by RDC No. 12 of January 2, 2001, of the National Sanitary Surveillance Agency (Brazil, 2001).

To evaluate the physico-chemical characteristics of the freeze-dried extracts the following analyses were carried out: moisture (method 925.10), proteins (method 923.03), ashes (method 979.09) and lipids (method 922.06), according to the methodologies proposed by the Association of Official Analytical Chemists (AOAC, 2010).

The sensorial analysis was carried out with a team of fifteen judges of both genders, aged between 18 and 32 years, selected because they are habitual consumers of shrimp and have facilities for the identification of aromas and flavors, as evidenced by previous tests. The judges evaluated taste and aroma parameters using a structured nine-point scale $(9=$ greatly liked $1=$ greatly disliked) as specified by Stone and Sidel (1985).

To be served in the sensory analysis, the dry extracts obtained through freeze-drying were reconstituted in the same proportion of total solids in the extracts prior to freeze-drying, adding $1 \%$ salt and $0.25 \%$ monosodium glutamate to enhance the meat flavor. In the test room, $25 \mathrm{~mL}$ of the reconstituted extract was served to each evaluator at a temperature between 45 and $50^{\circ} \mathrm{C}$, so that the judges could better understand the volatiles released, following the methodology proposed by Takeshita (1981).

In order to obtain the index of acceptability (IA) of the aromatic extract, the following expression was used:

$$
\mathrm{IA}(\%)=\mathrm{A} \times 100 / \mathrm{B}
$$

where, $\mathrm{A}=$ average grade obtained for the product; $\mathrm{B}=$ maximum grade given to the product (Teixeira, Meinert, \& Barbetta, 1987).

\subsection{Calculation of Extraction Yield}

Calculation of the extraction yield was performed in relation to the weight of the extracts before and after freeze-drying according to Equation 1:

$$
\mathrm{Rd}=(\mathrm{Pf} / \mathrm{Pi}) \times 100
$$

where, $\mathrm{Rd}(\%)=$ Yied; Pf $(\mathrm{g})=$ Final weight of freeze-dried extract; Pi $(\mathrm{g})=$ Initial weight of the liquid extract before freeze-drying.

\subsection{Statistical Analyses}

In the data generated from the physical-chemical analyses and the acceptance test of the extracts, the means and the standard deviations were calculated and the Analysis of Variance (ANOVA) was performed, later, the means were compared by the Tukey test, at the level of $5 \%$ of significance by the software ASSISTAT, version 7.7 (Silva \& Azevedo, 2016).

\section{Results and Discussion}

\subsection{Physico-Chemical Composition of Freeze-Dried Extracts}

Table 1 shows the mean values of the physico-chemical composition of the freeze-dried extracts. 
Table 1. Physico-chemical characterization of freeze-dried extracts obtained from L. vannamei shrimp waste

\begin{tabular}{lllll}
\hline Treatments & Humidity & Ashes & Proteins & Lipids \\
\hline $\mathbf{E}_{\text {casca }}$ & $9.18 \pm 0.05^{\mathrm{a}^{*}}$ & $17.67 \pm 0.11^{\mathrm{a}}$ & $70.01 \pm 0.11^{\mathrm{a}}$ & $0.75 \pm 0.21^{\mathrm{c}}$ \\
$\mathbf{E}_{\text {cefa }}$ & $9.04 \pm 0.07^{\mathrm{a}}$ & $10.46 \pm 0.06^{\mathrm{c}}$ & $63.71 \pm 0.14^{\mathrm{b}}$ & $12.04 \pm 0.07^{\mathrm{a}}$ \\
$\mathbf{E}_{\text {mix }}$ & $9.21 \pm 0.08^{\mathrm{a}}$ & $10.69 \pm 0.06^{\mathrm{b}}$ & $61.50 \pm 0.07^{\mathrm{c}}$ & $7.73 \pm 0.23^{\mathrm{b}}$ \\
\hline
\end{tabular}

Note. $\mathrm{E}_{\text {casca }}=$ extract obtained from shells; $\mathrm{E}_{\text {cefa }}=$ extract obtained from cephalothorax; $\mathrm{E}_{\text {mix }}=$ extract obtained from $50 \%$ shells and $50 \%$ cephalothorax. ${ }^{*}$ Different letters in the same column differ significantly by the Tukey test at the $5 \%$ level of significance.

In Table 1 it is possible to observe that with the exception of humidity, all other physical-chemical parameters presented significant differences among themselves at the $5 \%$ significance level of the Tukey test. The freeze-drying process altered the percentages of raw material components in natura, since with the reduction of the amount of water, an increase in the concentration of lipids, proteins and ashes occurred.

The moisture contents of freeze-dried extracts are close to those found by Corrêa, Macedo, Moraes, Machado, and França (2012) who evaluated the extraction of an aromatic extract from the cephalothorax of L. vannamei shrimp, obtaining a content of $8.75 \%$. The moisture values in Table 1 are in accordance with the Regulation of the Industrial and Sanitary Inspection of Products of Animal Origin (Brazil, 2017), which describes that whole dry fish should not contain more than $12 \%$ moisture. Therefore, the aromatic extracts obtained in this work are within the recommended so that their sensorial and nutritional characteristics are not affected.

Evaluating the viability of flour preparation obtained through the drying process of shrimp cephalothorax of the L. vannamei species, Savay-da-Silva et al. (2016) found an ash value of $18.28 \%$, while Mendes and Bandeira (2016), when evaluating the ash content in gray shrimp meal, obtained values of $17.77 \%$, values close to the extract obtained from shells $\left(\mathrm{E}_{\text {casca }}=17.67 \%\right)$ reported in this research. According to Freitas, Borges, Costa, Cornejo and Wilberg (2002), the high content of ash in the flour and consequently in aromatic extract shows a potential of these products for use in diets for special purposes.

The protein values (Table 1) of the aromatic extracts were higher than those found in the L. vannamei cephalothorax meal by Azevedo (2014), and Savay-da-Silva et al. (2016), which were 39.3\% and 51.57\%, respectively. In the case of shrimp fillets of the same species, protein values of $21.9 \%$ were found by Araújo et al., (2012) and $20.28 \%$ by Pereira (2014), lower values than those found in this research for aromatic extracts. This indicates that shrimp waste can be used as an alternative protein source compared to fillet.

The lipid contents of the $\mathrm{E}_{\text {casca }}(0.75 \%)$ and $\mathrm{E}_{\text {mix }}(7.73 \%)$ extracts had significant variations and significant differences when compared to the extract obtained exclusively from the cephalothorax $\left(\mathrm{E}_{\text {cefa }}=12.04 \%\right)$. According to Bragagnolo and Rodriguez-Amaya (1997), the shrimp fat deposit is located in the hepatopancreas, which is situated in the head region, so the aromatic extract produced only from the cephalothorax had a lipid content higher than the other extracts.

According to Luzia, Sampaio, Castelluci, and Torres (2003), the lipid content is influenced by seasonality, since significant differences between shrimp (Xiphopenaeus kroyeri) in summer $(0.94 \%)$ and winter $(1.16 \%)$ were evidenced by these authors. Still according to Freitas et al. (2002), these levels may also vary according to age and degree of sexual maturation.

\subsection{Microbiological Evaluation of Extracts}

According to Resolution no. 12 of January 2, 2001 (Brazil, 2001), in products derived from fish, the presence of Salmonella sp. in $25 \mathrm{~g}$ must not be detected, since it is a potentially pathogenic bacterium. In this research the presence of Salmonella sp. was not detected in any of the elaborate aromatic extracts. Regarding the research of coliforms at $45{ }^{\circ} \mathrm{C}$, the values found in this research were within normal limits when compared to products derived from precooked fish (maximum of $1 \times 102 \mathrm{NMP}^{-1}$ ) (Brazil, 2001). The positive Staphylococcal coagulase count was also within the limits allowed by Resolution 12 (Brazil, 2001).

All the extracts produced were within acceptable standards for human consumption, according to what is recommended by Resolution No. 12 of the National Health Surveillance Agency (Brazil, 2001), showing that all extracts produced from shrimp waste can be satisfactorily used for human consumption from a microbiological point of view.

\subsection{Sensory Evaluation of Extracts}

Table 2 shows the mean values of the sensory evaluation of freeze-dried extracts. 
Table 2. Odor and taste parameters of freeze-dried aromatic extracts

\begin{tabular}{llll}
\hline Attribute & $\mathbf{E}_{\text {casca }}$ & $\mathbf{E}_{\text {cefa }}$ & $\mathbf{E}_{\text {mix }}$ \\
\hline Aroma & $6.87 \pm 0.93^{\mathrm{b}^{*}}$ & $8.15 \pm 0.50^{\mathrm{a}}$ & $7.09 \pm 0.67^{\mathrm{b}}$ \\
Flavor & $6.81 \pm 0.72^{\mathrm{c}}$ & $8.03 \pm 0.75^{\mathrm{a}}$ & $7.32 \pm 0.82^{\mathrm{b}}$ \\
\hline
\end{tabular}

Note. $\mathrm{E}_{\text {casca }}=$ extract obtained from shells; $\mathrm{E}_{\text {cefa }}=$ extract obtained from cephalothorax; $\mathrm{E}_{\operatorname{mix}}=$ extract obtained from $50 \%$ shells and $50 \%$ cephalothorax. *Different letters on the same line differ significantly by the Tukey test at the $5 \%$ level of significance.

It can be observed in Table 2 that the $\mathrm{E}_{\text {casca }}$ treatment differed significantly from the others in relation to the aroma and flavor attribute. The $\mathrm{E}_{\text {casca }}$ sample that used only the cephalothorax as the raw material obtained a mean score of 8.15 for the aroma and 8.03 for the flavor, which correspond to the term "I liked it a lot". The treatments $\mathrm{E}_{\text {casca }}$ and $\mathrm{E}_{\text {mix }}$ received notes corresponding to the terms "I liked it a little" and "I liked it moderately", respectively.

The mean scores found in this study for the $\mathrm{E}_{\text {cefa }}$ treatment were higher than those found by Takeshita (1981), who, when sensory evaluation of a freeze-dried aromatic extract obtained from waste industries of Xiphopenaeus kroyeri obtained an average grade for the aroma and flavor attributes of 7.35 and 7.55 respectively.

It can be observed from the results found (Table 2) that the $E_{\text {mix }}$ extracts and especially $E_{\text {cefa }}$, had a good acceptance in relation to the evaluated attributes, which proves satisfactory sensorial characteristics, being an indicative for its use in food products that can present a shrimp taste and aroma.

Regarding the acceptability index (Figure 2), it is possible to say, with the exception of the flavor of the $\mathrm{E}_{\text {casca }}$ treatment, that all the attributes of the extracts were well accepted, with a variation of $76.33 \%$ for the aroma of sample E1 to $90.55 \%$ for the aroma of sample E2. According to Teixeira, Meinert, and Barbetta (1987), for a product to be considered accepted in terms of its sensorial properties, it is necessary that it obtain an acceptability index of at least $70 \%$. Thus, data from Figure 2 reinforce the feasibility of elaborating a shrimp-flavored extract obtained from wastes from the processing industries of these crustaceans.

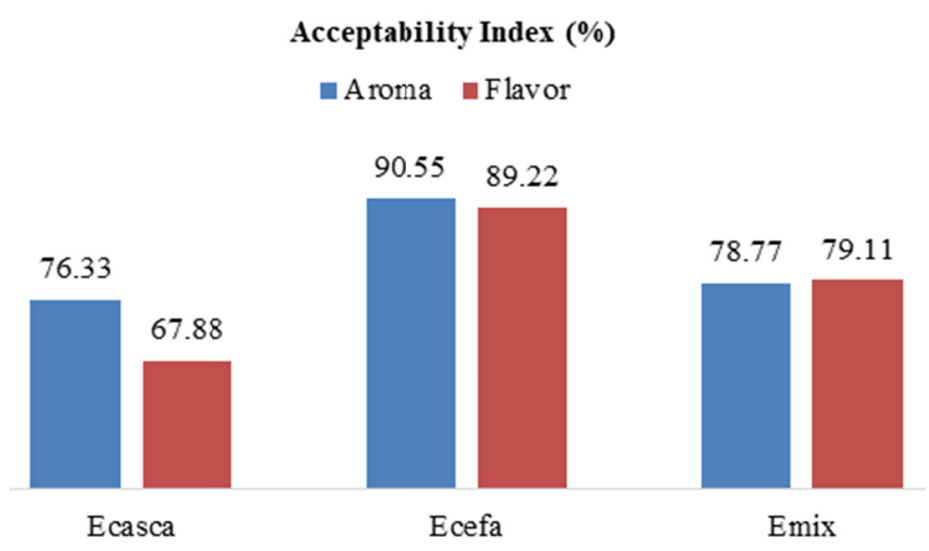

Figure 2. Acceptability index of shrimp flavor extracts

Source: R. Bernadino Filho, 2018.

\subsection{Calculation of Extraction Yield}

Table 3 shows the average values of the liquid extracts obtained from cooking, the freeze-dried extracts and the calculation of the extraction yield after freeze-drying. 
Table 3. Yield of freeze-dried extracts

\begin{tabular}{llll}
\hline & $\mathbf{E}_{\text {casca }}$ & $\mathbf{E}_{\text {cefa }}$ & $\mathbf{E}_{\text {mix }}$ \\
\hline Initial waste amount (g) & 1,000 & 1,000 & 1,000 \\
Weight of water added (g) & 500 & 500 & 500 \\
Total weight of the liquid extract (g) & 665 & 925 & 850 \\
Freeze-dried extract weight (g) & 16.42 & 79 & 43.6 \\
\hline Yield of initial weight (\%) & 1.09 & 5.27 & 8.54 \\
\hline Yield of liquid extracts (\%) & 2.47 & 5.13 \\
\hline
\end{tabular}

Analyzing Table 3, it can be deduced that the $\mathrm{E}_{\text {casca }}$ treatment obtained the lowest weight of liquid extract and consequently a smaller amount of freeze-dried extract, reaching an extraction yield of only $2.47 \%$, followed by $\mathrm{E}_{\text {mix }}$ treatment with $5.13 \%$. The $\mathrm{E}_{\text {cefa }}$ sample obtained the highest yield, thus being close to the value obtained by Takeshita (1981), which was 9\%, when evaluating the extraction yield of aromatic extracts obtained from the waste of industries waste of Xiphopenaeus kroyeri shrimp.

\section{Conclusions}

All the extracts showed good physico-chemical characteristics with high levels of protein. The sensorial tests of aroma and flavor indicated a good acceptance of the extracts, mainly of the $\mathrm{E}_{\text {cefa }}$ treatment that presented the greater index of acceptability. The results showed that waste from the industrial processing of white shrimp can be used to obtain an extract with characteristics typical of shrimp and as an alternative for the utilization of the by-products of the carcass industry, thus contributing to the preservation of the environment.

In view of the data obtained, it is possible to conclude that the extract prepared only from the cephalothorax $\left(\mathrm{E}_{\text {cefa }}\right)$, both in relation to the acceptability index and in the extraction yield, has a greater potentiality of applicability as raw material in the elaboration of an extract, contributing of this way to obtain food with aroma and flavor of shrimp.

\section{References}

AOAC (Association of Official Analytical Chemists). (2010). Official Methods of Analysis (18th ed.). Washington, USA.

APHA (American Public Health Association). (2001). Compendium of methods ofthe microbiological examination of foods (4th ed.). Washington D.C., USA.

Araújo, D. F. S., Silvestre, D. D., Damasceno, K. S. F. S. C., Pedrosa, L. F. C. P., \& Seabra, L. M. J. (2012). Composição centesimal e teor de colesterol do camarão branco do Pacífico. Ciência Rural, 42(6), 1130-1133. https://doi.org/10.1590/S0103-84782012000600029

Azevedo, M. S. P. (2014). Processamento e Avaliação Nutricional da Farinha de Resíduos de Camarão para Frangos de Corte. Universidade Federal de Sergipe, São Cristóvão, São Paulo.

Basilio, F. F. F., Ogawa, M., Perdigão, N. B., \& Vasconcelos, F. C. (2003). Elaboração de saborizante líquido e em pó de cabeça de camarão. XIII CONBEP, Porto Seguro.

Bragagnolo, N., \& Rodriguez-amaya, D. B. (1997). Otimização da determinação de colesterol por CLAE e teores de colesterol, lipídeos totais e ácidos graxos em camarão rosa (Penaeus brasiliensis). Ciência e Tecnologia de Alimentos, 17(3), 275-280. https://doi.org/10.1590/S0101-20611997000300016

Brazil. (2001). Ministério da Saúde, Agência Nacional de Vigilância Sanitária (ANVISA). Regulamento técnico sobre padrões microbiológicos para alimentos (Resolução RDC $\mathrm{n}^{\circ} 12$, de 02/01/2001). Diário Oficial da União, Brasília, DF. Retrieved from http://www.anvisa.gov.br

Brazil. (2017) Ministério da Agricultura, Pecuária e Abastecimento (MAPA). Regulamento da Inspeção Industrial e Sanitária de Produtos de Origem Animal (Pescados e Derivados, C.7, Seção 1). Diário Oficial da União, Brasília, DF. Retrieved from http://www.agricultura.gov.br/sislegis

Corrêa, N. C. F., Macedo, C. S., Moraes, J. F. C., Machado, N. T., \& França, L. F. (2012). Characteristics of the extract of Litopenaeus vannamei shrimp obtained from the cephalothorax using pressurized $\mathrm{CO}_{2}$. Journal of Supercritical Fluids, 66, 176-180. https://doi.org/10.1016/j.supflu.2012.02.013 
Freitas, A. S., Borges, J. T. S., Costa, R. K, Cornejo, F. E. P., \& Wilberg, V. C. (2002). Teores de lipídeos totais, ácidos graxos e colesterol em resíduos desidratados de camarão-sete-barbas (Xiphopenaeus kroyeri) capturado no Estado do Rio de Janeiro. Boletim CEPPA, 20(2), 355-362.

Gonçalves, A. G. (2011). Tecnologia do pescado: Ciência, tecnologia, inovação e legislação (1st ed.). São Paulo/SP. Atheneu.

Gildberg, A., \& Stemberg, E. (2001). A new process for advanced utilization of shrimp waste. Process Biochemistry, 36, 809-812. https://doi.org/10.1016/S0032-9592(00)00278-8

Luzia, L. A., Sampaio, G. R., Castelluci, C. M. N., \& Torres, E. A. F. S. (2003). The influence of season on the lipid profiles of five commercially important species of Brazilian fish. Food Chemistry, 83, 93-97. https://doi.org/10.1016/S0308-8146(03)00054-2

Mendes, A. G. G., \& Bandeira, M. G. A. (2016). Obtenção e caracterização físico-química de quitosana a partir de cascas de camarão cinza. XXV Congresso brasileiro de ciência e tecnologia de alimentos, Gramado, Rio Grande do Sul, Brazil. Retrieved from http://www.ufrgs.br/xxvcbcta/anais

Nogueira, W. M. (2006). Utilização de resíduos de Piramutaba (Brachyplatystoma vaillantii) para obtenção de surimi utilizado na elaboração de salsicha sabor camarão. Relatório apresentado ao Curso de Engenharia de Pesca-Instituto Sócio Ambiental e dos Recursos Hídricos, Universidade Federal Rural da Amazônia, Belém.

Pereira A. C. S. C. (2014). Efeitos da radiação ionizante na qualidade do camarão branco do pacífico (Litopenaeus vannamei). Universidade Federal da Paraíba, João Pessoa, Paraíba.

Rocha, M. M. R. M., Nunes, M. L., \& Fioreze, R. (1998). Composição química da porção muscular e da farinha de resíduos do camarão marinho Penaeus vannamei (Vol. 2, pp. 1166-1169). XVI Congresso Brasileiro de Ciência e Tecnologia de Alimentos, Rio de Janeiro. Anais... Rio de Janeiro, Brazil.

Savay-da-silva, L. K., Vieira, S. G. A., Santos-filho, L. A., Pereira, A. M. L., Magalhães, J. A., \& Fogaça, F. H. S. (2016). Qualidade nutricional da farinha de subprodutos de camarão Litopenaeus vannamei. VII Simpósio de Controle de Qualidade do Pescado, São Paulo.

Seibel, N. F., \& Soares, L. A. S. (2003). Produção de Silagem Química com Resíduos de Pescado Marinho. Brazilian Journal of Food Technology, 6(2), 333-337.

Silva, F. de A. S., \& Azevedo, C. A. V. de. (2016). The Assistat Software Version 7.7 and its use in the analysis of experimental data. Afr. J. Agric. Res, 11(39), 3733-3740. https://doi.org/10.5897/AJAR2016.11522

Stone, H., \& Sidel, J. L. (1993). Sensory Evaluation Practices. Academic Press, London.

Takeshita, M. (1981). Obtenção de um extrato aromático de camarão a partir de seus resíduos industriais (Dissertação (Mestrado em Tecnologia de Alimentos), Universidade Estadual de Campinas, Campinas).

Teixeira, E., Meinert, E. M., \& Barbetta, P. A. (1987). Análise sensorial de alimentos. Florianópolis, Santa Catarina.

\section{Copyrights}

Copyright for this article is retained by the author(s), with first publication rights granted to the journal.

This is an open-access article distributed under the terms and conditions of the Creative Commons Attribution license (http://creativecommons.org/licenses/by/4.0/). 